\title{
TERAPI LARVA PADA LUKA KRONIS TERBUKA
}

\author{
Sunny Wangko \\ Bagian Anatomi-Histologi Fakultas Kedokteran Universitas Sam Ratulangi Manado \\ Email: sunnywangko@yahoo.com
}

\begin{abstract}
The usage of larvae in wound treatment has been known across the centuries in different countries. However, larval therapy is offered when the conventional therapy has failed in the management of chronic, infected wounds. Concerning the larval therapy, it was presumed that the wound healing was due to the mechanical debridement effect of the larval movement and of their hooks. To date, a variety of study reports reveals that there are several beneficial effects of the larval therapy, inter alia: secretion/excretion of larvae contains enzymes, growth factors, and cytokines that collaborate in the wound healing process. The bioactive molecules in the secretion/excretion of the larvae has to be further studied and to be developed, therefore, they can be applied in the wound management efficiently and economically.
\end{abstract}

Keywords: larval therapy, chronic wound, healing process.

\begin{abstract}
Abstrak: Walaupun pemanfaatan larva pada luka kronis telah sangat lama dikenal di berbagai negara, terapi larva umumnya digunakan bila terapi konvensional telah gagal. Awalnya diduga bahwa efek debridemen mekanis oleh gerakan larva dan kaitnya yang paling berperan. Dewasa ini, laporan berbagi studi telah mengungkapkan bahwa larva menyekresi dan menyintesis berbagai bahan baik berupa enzim, sitokin, dan growth factors yang turut berperan dalam proses penyembuhan luka. Adanya molekul bioaktif dalam ekskresi dan sekresi larva perlu diteliti dan dikembangkan agar dapat diaplikasikan dengan lebih efisien dan ekonomis.
\end{abstract}

Kata kunci: terapi larva, luka kronis, penyembuhan luka.

Umumnya larva serangga lebih dikenal dari dampak yang merugikan kehidupan manusia antara lain: sebagai hama tanaman, penyebab miasis pada manusia dan hewan ternak, mengganggu kenyamanan, dan merupakan bentuk pradewasa dari serangga sebagai vektor penyakit. Pada hakekatnya, larva sangat berperan dalam kehidupan manusia. Daur ulang (recycling) sampah, tanaman rusak, serta bangkai dan mayat, keikutsertaannya dalam rantai makanan, dan pemanfaatan dalam berbagai komoditi misalnya larva ulat sutera menunjukkan manfaat larva terhadapan kehidupan. Dewasa ini, pemanfaatan larva, khususnya larva lalat, telah ditinjau kembali untuk perawatan luka terutama luka kronis terbuka yang telah memboroskan biaya pengobatan yang cukup tinggi baik di negara maju maupun negara terkebelakang.

Pemanfaatan larva dalam perawatan luka (terapi larva) sebenarnya telah dikenal sejak berabad-abad yang lalu, kemudian dikemukakan oleh beberapa ahli bedah di Prancis pada abad ke-16 dan abad ke 1819. Terapi ini mulai ditinggalkan sejak ditemukannya antibiotik (1940), tetapi kemudian setelah terjadinya peningkatan resistensi kuman terhadap antibiotik terapi larva ditinjau kembali,, ${ }^{1,2}$ terutama pada luka kronis yang terinfeksi oleh methicillinresistant Staphylococcus aureus (MRSA) dan patogen yang resisten lainnya. ${ }^{3}$ 
Awalnya, masalah yang dihadapi pada terapi larva ialah bagaimana memperoleh larva yang steril dan hidup (medicalgrade). Dengan kemajuan teknologi, larva yang digunakan lebih terjamin kualitasnya dan telah dijinkan oleh USA Food and Drug Administration (FDA) pada tahun 2004. ${ }^{2,4}$ Sejauh ini larva yang umum digunakan ialah larva lalat Lucilia sericata yang bersifat nekrofagus. ${ }^{1-3,5-9}$

Terdapat beberapa istilah yang dipakai untuk perawatan luka terbuka dengan menggunakan larva yaitu: terapi larva, larval therapy, maggot debridement therapy/MDT, biosurgery, biodebridement, dan controlled therapeutic myasis., ${ }^{2,5-7,9}$ Telaah ini bertujuan untuk mengemukakan keunggulan terapi larva yang sejauh ini belum dimanfaatkan di Indonesia.

\section{SEJARAH}

Pemanfaatan larva dalam perawatan dan pengobatan luka kronis terbuka telah dikenal sejak berabad-abad lalu. ${ }^{1,3,10,11}$ Perawatan luka dengan menggunakan larva pertama kali dikenal pada suku Maya Indian di Amerika, penduduk aborigin Australia, ${ }^{2,11,12}$ dan di Cina. ${ }^{2,5}$ Pada abad ke-16 (1557), Ambroise Pare (seorang ahli bedah kekaisaran Prancis Charles IX dan Henri III) melaporkan manfaat larva pada luka-luka prajurit selama perang. ${ }^{5,11}$ Pada abad ke 18-19 (1829) Baron Dominique Jean Larrey (seorang ahli bedah zaman Kekaisaran Napoleon) yang pertama melaporkan secara tertulis bahwa larva hanya menyerang jaringan nekrotik dan terapi larva dapat meningkatkan pembentukan jaringan granulasi serta memicu penyembuhan luka terinfeksi yang ditemukan pada prajurit. $^{2,5,11}$ Selama perang saudara di Amerika, Joseph Jones dan J. F. Zacharias (ahli bedah sekutu) mulai menggunakan larva untuk pengobatan luka dan mencatat bahwa dalam beberapa hari larva telah membersihkan luka jauh lebih baik dari bahan-bahan yang direkomendasikan saat itu. ${ }^{2,5,6,11}$

Pada era pre-antibiotik (1920-an dan 1930-an), studi mengenai terapi larva pertama kali dikemukakan oleh William S. Baer (1929), seorang ahli bedah ortopedik dari John Hopkins Hospital di Baltimore, Maryland. ${ }^{5,8,10,11}$ Bear menggunakan larva yang steril untuk mengobati luka-luka prajurit selama perang dunia I dan melaporkan bahwa luka pada fraktur terbuka dan luka pada abdomen yang dinfestasi beribu-ribu larva memperlihatkan pertumbuhan jaringan granulasi yang sehat. Juga pada kasus osteomielitis anak, terapi larva menghasilkan debridemen yang cepat, menurunkan jumlah bakteri, mengurangi bau, dan alkalinisasi alas luka. ${ }^{2}$ Dalam era tersebut, mortalitas luka jenis demikian mencapai hampir $75 \%{ }^{11}$ Sekitar tahun 1935, terapi larva telah digunakan pada banyak rumah sakit di Amerika, Kanada, dan Eropa. ${ }^{5}$ Terapi larva juga digunakan pada ulkus mamae, luka bakar, abses, karsinoma sel skuamous, dan mastoiditis subakut. ${ }^{11}$ Kendala pada saat itu (tahun 1930-an) ialah menyiapkan kemasan untuk aplikasi larva, kesulitan memperoleh larva bebas kuman yang hidup, dan biaya yang tinggi ( $\$ 5$ pada 1933). ${ }^{8}$ Dengan adanya kemajuan dalam tehnik pembuatan pembalut dan perekat yang lebih nyaman (seperti cage-like dressings) serta dapat mempertahankan larva pada alas luka; desinfektan dan tehnik rearing yang sangat mendukung produksi larva yang medicalgrade; dan transportasi yang menjamin pengiriman larva ke lokasi, diharapkan terapi larva akan dapat digunakan secara lebih luas. ${ }^{8}$

Pada era antibiotik (perang dunia II), dengan ditemukannya antibiotik penicillin oleh Alexander Flemming $(1928)^{2}$ dan sulfa yang ampuh terhadap berbagai jenis bakteri dan didukung oleh tehnik pembedahan yang lebih baik, maka pada tahun 1940 terapi larva mulai ditinggalkan.,8,10,11 Munculnya resistensi berbagai strain kuman terhadap antibiotik dan meningkatnya insidensi luka dengan vaskularisasi yang kurang memicu reintroduksi terapi larva pada tahun1980an di Amerika, Inggris, dan negara Eropa lainnya. $^{1,2,8}$ Pada tahun 1990-an, Sherman et al di Amerika Serikat dan Mumcouglu et 
al di Israel mereintroduksi terapi larva untuk pengobatan luka kronis. ${ }^{6}$

Pada tahun 2004, US Food and Drug Administration telah mengijinkan penggunaan terapi larva dengan indikasi debridemen untuk luka kulit kronis dengan jaringan nekrotik dan luka pada jaringan ikat, termasuk ulkus akibat tekanan (pressure ulcer), ulkus stasis venosa, ulkus neuropatik pada kaki, dan luka pasca operasi yang tidak menyembuh. ${ }^{2,4}$

\section{LUKA KRONIS}

Dengan bertambahnya usia harapan hidup maka jumlah pasien dengan luka kronis akibat berbagai penyakit, terutama diabetes melitus dan penyakit pembuluh darah perifer turut meningkat. Luka kronis tidak mengikuti fase-fase penyembuhan luka, tetapi akan berhenti pada fase inflamasi akibat adanya debris nekrotik dan infeksi. ${ }^{2,5}$

Debridemen ialah tindakan mengeluarkan debris asing nekrotik atau jaringan terkontaminasi dari alas luka (wound bed) sehingga jaringan sekitar yang sehat akan terbuka. Debridemen dapat dilakukan dengan berbagai cara. Salah satu cara yang telah lama dikenal ialah maggot debridement therapy (MDT) atau terapi larva. Dalam hal ini, larva lalat yang medical-grade diaplikasikan pada luka untuk menghasilkan debridemen, desinfeksi, dan penyembuhan luka (artificially induced myasis)., ${ }^{2,3,5}$

\section{DESKRIPSI LARVA YANG DIGUNA- KAN PADA TERAPI LARVA}

Umumnya yang digunakan untuk terapi larva ialah larva Phaenicia (Lucilia) sericata (Ordo Diptera, famili Calliphoridae), yang tergolong dalam green bottle fly (Gambar 1). ${ }^{2,3,5-9}$ Larva hanya memakan jaringan nekrotik dan tidak mengganggu atau menyusup ke dalam jaringan sehat. Phormia regina (blackbottle fly) juga dilaporkan dapat digunakan untuk terapi larva. ${ }^{6,11}$

Siklus hidup Phaenicia (Lucilia) sericata berlangsung sekitar 10-14 hari. Telur menetas setelah sekitar 12-24 jam. Pertumbuhan larva dari instar 1 sampai dengan instar 3 (wondering larval stage) berlangsung selama beberapa hari (3-7 hari) hingga mencapai ukuran sekitar 10 mm, kemudian larva (prepupa) akan mencari tempat untuk melakukan pupasi. Masa pupasi berkisar 7-20 hari, tergantung pada suhu dan cuaca (Gambar 2). 5,6,8,9

Larva yang akan digunakan untuk terapi larva harus steril (bebas bakteri) untuk mencegah terjadinya kontaminasi saat diaplikasikan pada luka. Larva diperlihara pada lingkungan yang lembab dan steril untuk mendapatkan larva yang medical grade.,11 Telur dicuci dengan larutan antiseptik dan ditempatkan di dalam wadah steril yang berisi brewer's yeast dan kedelai sebagai sumber makanan agar larva tetap bertahan hidup sampai dapat ditranspor dalam wadah steril untuk kebutuhan terapi larva. ${ }^{11}$

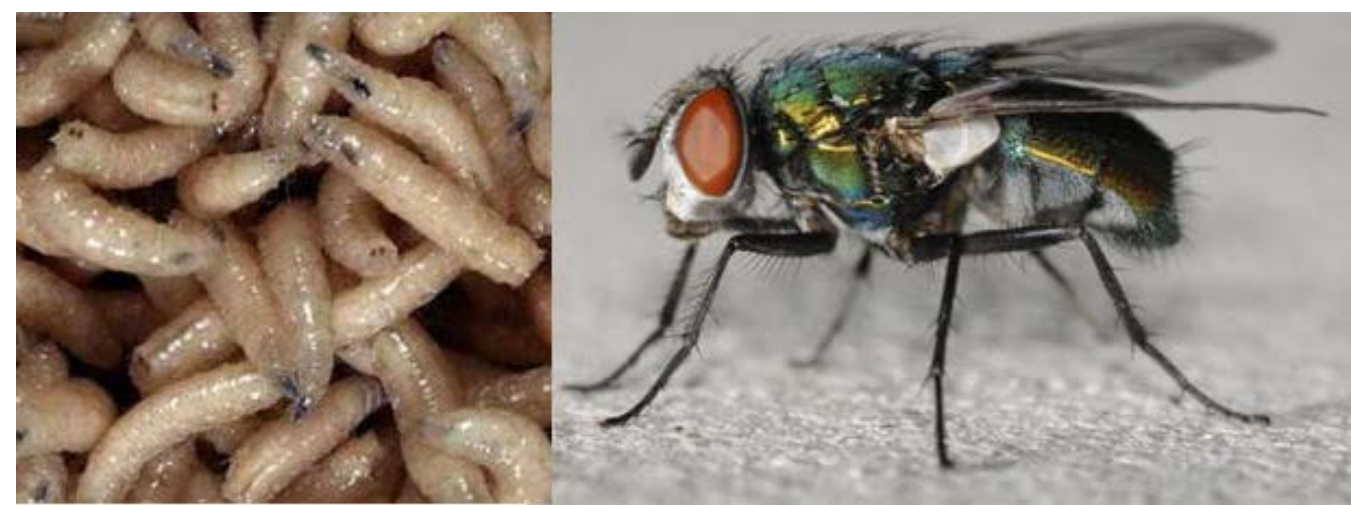

Gambar 1. Phaenicia (Lucilia) sericata. A, Larva. B, Serangga dewasa. Sumber: Derraik JGB et al, $2010 .{ }^{13}$ 


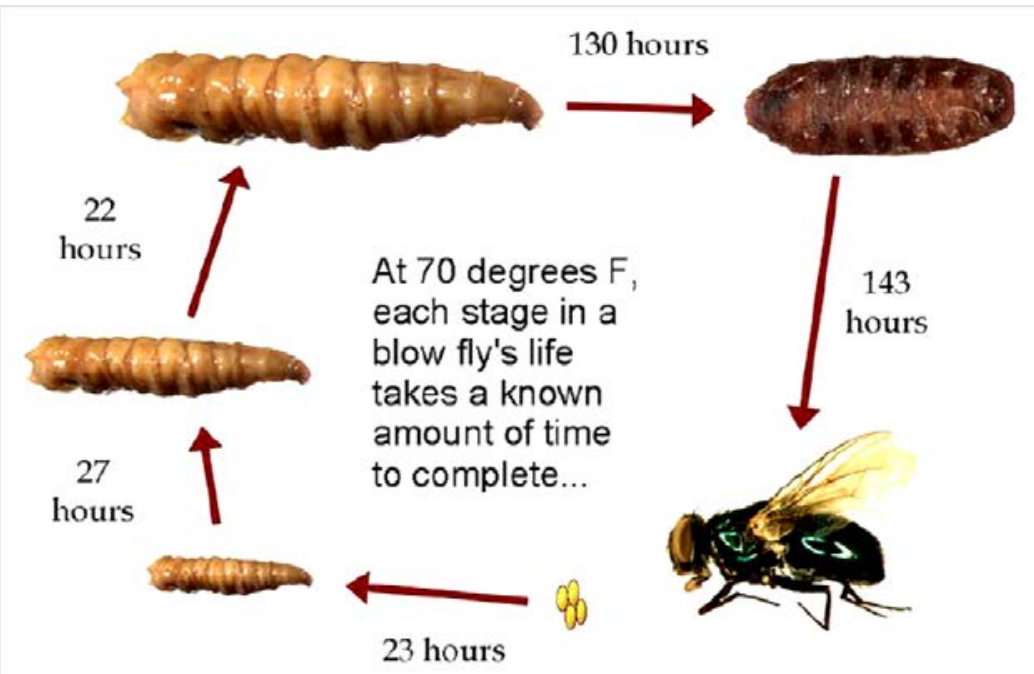

Gambar 2. Siklus hidup blow fly yang terdiri dari 6 tahap: telur, larva instar 1, instar 2, instar 3, pupa, dan lalat dewasa. Sumber: anonim. ${ }^{14}$

Pada terapi larva, sekitar 5-10 ekor larva diaplikasikan per $\mathrm{cm}^{2}$ luka., ${ }^{7,9,11}$ Larva yang digunakan ialah instar 1 berukuran panjang sekitar $2 \mathrm{~mm}$ (1-3 mm) dan dapat berkembang menjadi $8-10 \mathrm{~mm}$ setelah 5-7 hari. Selama 48-72 jam larva bergerak pada permukaan luka sambil menyekresi sekret yang berpotensi memecahkan dan mencairkan jaringan nekrotik. ${ }^{7,8,11}$ Larva dapat digunakan bersama antibiotik sistemik, dan juga tidak memperlihatkan efek merugikan pada Xray sehingga larva dapat dibiarkan pada tempatnya saat dilakukan tindakan tersebut. $^{11}$

\section{MANFAAT TERAPI LARVA}

Manfaat terapi larva telah dilaporkan oleh berbagai studi yang tersebar di seluruh dunia. Terapi larva dapat mempercepat penyembuhan luka, ${ }^{15}$ menurunkan masa penggunaan antibiotik, ${ }^{3,10}$ mengurangi masa perawatan di rumah sakit, ${ }^{6-8}$ menurunkan risiko amputasi, ${ }^{3,6,10}$ menurunkan jumlah kunjungan pasien rawat jalan, relatif ekonomis, ${ }^{3}$ dan memperbaiki kualitas hidup. ${ }^{6}$ Beberapa kondisi pada terapi larva yang membantu penyembuhan luka kronis, yaitu:

1. Debridemen: Gerakan-gerakan mekanis dari larva dengan kaitnya pada permukaan sampai alas luka berfungsi sebagai debridemen yang dapat membersihkan luka dari jaringan nekrotik dan terinfeksi. ${ }^{4,5,9}$ Studi Opletalova et al. ${ }^{4}$ mendapatkan hasil debridemen dengan terapi larva lebih cepat dibandingkan terapi konvensional lainnya. Dibandingkan cara debridemen lainnya seperti hydrogel dressings, pengolesan madu, debridemen mekanis atau hydrosurgery, terapi larva memperlihatkan efisiensi ekonomis yg signifikan. ${ }^{16}$

2. Membersihkan jaringan nekrotik: Larva menghasilkan berbagai enzim proteolitik antara lain kolagenase yang memecahkan jaringan nekrotik dan matriks ekstrasel (termasuk laminin dan fibronektin) Chan menjadi bentuk semisolid yang dapat diabsorpsi dan dicernakan oleh larva. ${ }^{4,5,9,11}$

3. Desinfeksi luka: Larva memakan debris yang terinfeksi, menghasilkan bahan bakterisidal yang berspektrum luas terhadap bakteri Gram positif dan negatif, antara lain strain bakteri Staphylococcus sp. termasuk methicillin-resistant Staphylococcus aureus (MRSA), Bacillus sp., Escherichia Coli, Pseudomonas sp., Proteus sp., Enterococcus sp., dan Enterobacter sp. ${ }^{2,3,5,7}$ Larva juga 
menghasilkan amonia yang menyebabkan alkalinisasi, diduga dapat menghambat pertumbuhan bakteri.,

4. Irigasi luka oleh eksudat yang distimulasi oleh larva yang menelan jaringan nekrotik dan oleh sekret larva sendiri. ${ }^{3}$

5. Inhibisi dan eradikasi biofilm. Chymotrypsin dan DNAse dalam sekret larva dapat memecahkan protein yang menyusun biofilm. ${ }^{2,4}$

6. Menghasilkan growth factors: Larva menghasilkan alantoin, urea, dan bahan lainnya yang dapat bekerja sbagai growth factors. ${ }^{2,4,6,10}$

7. Menghasilkan sitokin, antara lain interferon dan interleukin 10 yang diduga mempercepat penyembuhan luka. ${ }^{5}$

8. Menghambat respons proinflamasi monosit melalui peningkatan cilik AMP oleh bahan yang disekresi dan diekskresi oleh larva. ${ }^{8}$

9. Menghambat proses inflamasi melalui pemecahan komponen komplemen yang berakibat turunnya aktivitas komplemen. ${ }^{2}$

10. Meningkatkan migrasi fibroblas., ${ }^{2,5}$

11. Berefek angiogenesis., ${ }^{2,7}$

\section{INDIKASI TERAPI LARVA}

Umumnya pasien dengan luka kronis yang tidak menyembuh jarang menolak untuk diberikan terapi larva.,

Indikasi untuk terapi larva ialah luka kronis yang tidak menyembuh disertai jaringan nekrotik. Sebagai contoh: ulkus akibat tekanan, ulkus venosa, ulkus diabetik, ulkus neuropatik (non-diabetes), ulkus iskemik/arterial, luka traumatik, luka bedah, tromboangitis obliterans, luka/ulkus pasca trauma, necrotizing fasciitis, pioderma gangrenosum, abses pada maleolus, osteomielitis sinus pilonidal, luka infeksi pasca bedah, luka akibat proses keganasan, luka bakar disertai infeksi MRSA, dan mastoiditis subakut. ${ }^{5,6}$

\section{KONTRAINDIKASI}

Terdapat kontraindikasi relatif dan kontraindikasi absolut untuk terapi larva.
Yang termasuk kontraindikasi relatif yaitu:

1. Luka yang kering, karena larva memerlukan lingkungan yang lembab. ${ }^{5}$

2. Pasien yang tidak memahami penggunaan terapi larva. ${ }^{6}$

3. Luka yang membutuhkan inspeksi yang sering. ${ }^{6}$

Yang termasuk kontraindikasi absolut yaitu:

1. Luka terbuka yang berhubungan dengan kavitas tubuh atau organ dalam. ${ }^{5,9}$

2. Luka yang dekat dengan pembuluh darah besar. ${ }^{5,9}$

3. Luka yang mudah berdarah.,

4. Tulang atau tendon yang nekrotik. ${ }^{6}$

5. Gangguan perdarahan (herediter atau farmakologik). ${ }^{6}$

6. Luka yang kurang vaskularisasi (peripheral vascular disease). ${ }^{6}$

7. Alas luka yang ditutupi kerak keras. ${ }^{6}$

8. Fistula yg belum dilakukan tindakan pembedahan. ${ }^{6}$

9. Alergi terhadap telur, kedelai, brewer's yeast, dan larva. ${ }^{5}$

10. Semua keadaan dimana debridemen merupakan kontraindikasi. ${ }^{6}$

\section{EFEK SAMPING TERAPI LARVA}

Selama pemberian terapi larva, efek samping yang sering ditemukan, antara lain:

1. Rasa tidak nyaman (yuk factor) baik untuk pasien, dokter, dan tenaga medis lainnya. ${ }^{5,6}$

2. Nyeri: Mumcouglu et al. ${ }^{17}$ melaporkan selama terapi larva nyeri ditemukan 41\% pada pemakai tea-bag like pouch (TBA) dan 38\% pada pemakai cagelike dressing (DA). Pemberian analgetika dilakukan dengan titrasi dosis, dan bila diperlukan dapat dilakukan blok saraf tepi. Courtenay et al. ${ }^{10}$ mendapatkan keluhan nyeri ringan sampai berat (umumnya nyeri sedang) 48-72 jam setelah larva diaplikasikan pada luka; nyeri dapat diatasi dengan analgetika. 
3. Perdarahan ringan. ${ }^{10}$

4. Pireksia: Terjadinya pireksia belum jelas, mungkin berhubungan dengan reaksi imunologik. ${ }^{5,10}$

5. Influenza-like symptoms (pireksia, malaise, keluhan saluran napas). ${ }^{10}$

6. Alergi terhadap bahan hidrokoloid pada pembalut. $^{10}$

7. Munculnya bau yang tidak enak pada aplikasi larva yang pertama kali, terlepasnya larva, atau larva yang mati akibat tekanan pembalut. $^{5}$

\section{KOMPLIKASI}

Komplikasi yang berat tidak pernah dilaporkan.,

\section{KEMASAN}

Terapi larva mudah diaplikasikan, relatif tidak mahal, dan tidak merusak flora normal dalam saluran cerna, atau meninggalkan residu yang merugikan seperti halnya antibiotik sistemik. ${ }^{11,16}$ Larva harus digunakan dalam 8 jam setelah erupsi dan disimpan pada suhu $8-10^{\circ} \mathrm{C} .^{9,18}$

Secara umum terdapat 2 kelompok kemasan larva yang tersedia untuk aplikasi klinis: free-range dan bio-bag (BioMonde). Pada kemasan free range, larva diaplikasikan langsung pada luka. Setiap aplikasi harus diganti setelah 3 hari. Kemasan ini sangat sesuai untuk luka yang bergaung atau berongga.,9,18 Bio-bag berupa kantong yang terdiri dari jaring poliester halus dengan sepotong foam untuk menyerap sekresi larva yang berlebihan. Kemasan bio-bag lebih praktis dan estetik, serta sesuai untuk pasien rawat jalan untuk menjamin tidak terlepasnya larva. Bio-bag harus diganti setelah 4 hari. ${ }^{9,18}$

Dengan kemajuan teknologi, telah dikembangkan berbagai kemasan larva, antara lain: single-piece, hinged, dan cagelike dressings. Kemasan demikian disebut maggot confinement dressings yang memberi akses pada larva ke luka secara bebas tetapi dapat mencegahnya untuk terlepas keluar. ${ }^{8}$

\section{SIMPULAN}

Terapi larva telah dikenal sejak berabad-abad yang lalu. Dengan ditemukannya antibiotik dan tehnik perawatan luka serta pembedahan yang lebih baik maka terapi larva ditinggalkan. Akibat terjadinya resistensi bakteri terhadap antibiotik maka terapi larva direintroduksi dan pada tahun 2004 telah diakui oleh FDA untuk pemakaian pada luka kronis terbuka.

Awalnya diduga terapi larva bermanfaat hanya sebagai debridemen mekanis, tetapi hasil-hasil penelitian melaporkan adanya berbagai bahan yang diduga turut membantu penyembuhan luka, antara lain enzim proteolitik, bahan antibakteri, growth factors, dan sitokin.

Terapi larva digunakan pada luka kronis terutama yang telah gagal dengan terapi konvensional. Dengan dikembangkannya molekul bioaktif yang terkandung dalam bahan sekresi dan ekskresi larva diharapkan terapi larva dapat digunakan secara luas untuk mendapatkan hasil yang lebih optimal dengan biaya yang cukup ekonomis.

\section{DAFTAR PUSTAKA}

1. Steenvorde P, Jacobi CE, van Doorn L, Oskam J. Maggot debridenet therapy of infected ulcers: Patient and wound factors influencing outcome - A study on 101 patients withy 117 wounds. Ann R Coll Surg Engl. 2007;89(6):596-602.

2. Cazander G, Pritchard DI, Nigam Y, Jung W, Nibbering PH. Multiple actions of Lucilia sericata larvae in hard-to-heal wounds. Prospects \& Overviews. Bioessays 35: 0000-0000. Wiley Periodicals, Inc., 2013. DOI 10.1002/bies.201300071. [cited 2014 Nov 5]. Available from: www.bioessays-journal.com.

3. Sun X, Jiang K, Chen J, Wu L, Lu H, Wang A, et al. A systematic review of maggot debridement therapy for chronically infected wounds and ulcers. International Joournal of Infectious Diseases. 2014;25:32-7.

4. Opletalova K, Blaizot $X$, Mourgeon B, Chene Y, Creveuil C, Combemale P, 
et al. Maggot therapy for wound debridement A randomized multicenter trial. Arch Dermatol. 2012;148(4):432-7.

5. Chan DCW, Fong DHF, Leung JYY, PAtil NG, Leung GKK. Maggot debridement therapy in chronic wound care. Hong Kong Med J. 2007;13(5):382-6.

6. Pearson C. Something old is new again: Debriding and reducing local wound infection with maggots. Wound Care Canada. 2007;5(2):22-6.

7. Rafter L. Larval therapy applied to a large arterial ulcer: an effective outcome.British Journal of Nursing. 2013 (Tissue vaibility supplement);22(6):S4-10.

8. Singh NM, Bhatia SK, Singh G. Maggots therapy in facilitating wound debridement: Present status. Medical journal of Dr. D. Y. Patil University. 2004;7(5):639-42.

9. Acton C. Technical guide. A know-how guide to using larval therapy for wound debridement. Wound essentials. 2007;2:156-9.

10. Courtenay M, Church JCT, Ryan TJ. Larva therapy in wound management. Journal of the Royal Society of Medicine. 2000;93:72-4.

11. Hinshaw J. Larval therapy: A review of clinical human and veterinary studies. World Wide Wounds. October 2000. [cited 2014 Nov 10]. Available from: http://www.worldwidewounds.com/200 0/oct/Janet-Hinshaw/Larval-TherapyHuman-and-Veterinary.html.
12. Thornton D, Berry M, Ralston D. Case report: maggot therapy in an acute burn. World Wide Wounds. [cited: 2014 Dec 6]. Available from: http://www. worldwidewounds.com/2002/august/Th ornton/larval-Therapy-Acute-Burn.html (Last modified: 2002 Aug 08).

13. Derraik JGB, Heath ACG, dan Rademaker M. Human myasis in New Zealand: imported and indigenouslyacquired cases; the species of concern and clinical aspects. NZMJ. 2010;123(1322):21-38.

14. The blow fly life cycle has six parts: the egg, three larval stages, the pupa, and adult. [cited 2015 Jan 3]. Available from: http://fineartamerica. com/featured/forensic-helper-life-cycleof-blow-fly-science-source.html.

15. Armstrong DH, Salas $P$, Short B, Martin BR, Kimbriel HR, Nixon BP, et al. Maggot therapy in "lower-extremity hospice" wound care: Fewer amputations and more antibiotic-freedays. J Am Podiatr Med Assoc. 2005;95:254-7.

16. Griffin $\mathbf{J}$. What nurses need to know about the application of larval therapy? JCN.2014;28(2):58-62.

17. Mumcouglu KY, Davidson E, Avidan A, Gilead L. Pain related to maggot debridement therapy [abstract]. J Wound Care. 2012;21(8):400-5.

18. Purser K, Heywood N. Maggot therapy use in wound management. Bath: Royal United Hospital Bath, 2012. 